Przegląd Badań Edukacyjnych Educational Studies Review

ISSN 1895-4308

nr 26 (1/2018), s. 87-108

ORYGINALNE

ARTYKUŁY

BADAWCZE

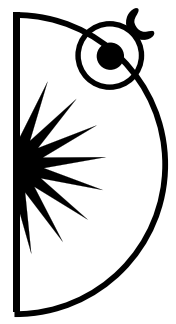

Alicja Zawistowska ORCID: 0000-0002-4145-9307

Uniwersytet w Białymstoku, Instytut Socjologii i Kognitywistyki; e-mail: a.zawistowska@uwb.edu.pl

\title{
Poczucie skuteczności i pozytywne autostereotypy - przypadek kobiet w naukach ścisłych i technicznych
}

http://dx.doi.org/10.12775/PBE.2018.005

\section{The Sense of Effectiveness and Positive Auto-Stereotypes - the Case of Women in Science and Engineering Fields}

\begin{abstract}
The paper focuses on the analysis of the social factors that contribute to women's access to mathematically-oriented fields. The study presented here utilizes data from 20 standardized qualitative interviews conducted with women studying in science and engineering fields. The theoretical framework of the article is the theory of self-efficacy by Albert Bandura. Following its predictions, an a strong sense self-efficacy regarding one's own mathematical competence is an important factor in choosing mathematical paths of studies. In addition, an important motivating role is also played by emotional arousal and vicarious experience.
\end{abstract}

Key words: mathematics, women, education, self-efficacy.

Dysproporcja płci w dziedzinie STEM (science, technology, engineering, mathematics) od co najmniej kilku dekad przyciąga uwagę naukowców, mediów i szerszej opinii społecznej. Intensywność badań dotyczących tej kwestii wynika między innymi z roli, jaką wiedza z zakresu nauk technicznych i matematycznych odgrywa we współczesnym świecie. Postęp technologiczny zawsze był zależny od dokonań w matematyce i innych naukach ścisłych, ale współcześnie związek ten wydaje się jeszcze silniejszy. Idei społeczeństwa opartego 
na wiedzy podporządkowane są też zmiany w polskiej edukacji. Powrót do obowiązkowej matury z matematyki oraz rządowe programy zachęcające do studiowania kierunków techniczny na uczelniach wyższych mogą być tego przykładem. Podejmowane są też pewne, zazwyczaj oddolne działania zachęcające kobiety do studiowania zmatematyzowanych kierunków. W ostatnich latach odnotowuje się systematyczny wzrost liczby kobiet na sporej liczbie kierunków politechnicznych - również tych, które dotychczas były zdominowane przez mężczyzn, między innymi informatycznych (Raport 2018). Badania wskazują jednak na istnienie wielu barier o charakterze społecznym, które nadal uniemożliwiają części kompetentnych kobiet podjęcie studiów politechnicznych. Dotyczą one w dużej mierze psychologicznych aspektów przebiegu nauki matematyki w okresie dorastania, między innymi nasilonego poczucia niepokoju matematycznego (Blickenstaff 2005, Cipora 2015), zaniżonej oceny własnych kompetencji matematycznych (Correll, 2001), czy poczucia zagrożenia stereotypem (Bedyńska, Dreszer 2008).

Mniej uwagi w praktyce badawczej poświęca się natomiast analizie czynników, które mają korzystny wpływ na osiąganie wysokich wyników z matematyki i sprzyjają późniejszym wyborom studiów politechnicznych przez dziewczęta. Właśnie te kobiety są bohaterkami niniejszego artykułu. W oparciu o analizę wywiadów jakościowych obejmujących grupę 20 studentek kierunków ścisłych i inżynieryjnych przedstawię, jak kobiety te postrzegają siebie oraz omówię kontekst ich dotychczasowych kariery szkolnych. Ramą teoretyczną podjętych analiz jest teoria poczucia własnej skuteczności sformułowana przez Alberta Bandurę (1977, 1997). Zgodnie z jej przewidywaniami, istotnym aspektem sprzyjającym wytrwałości w uczeniu się matematyki jest przekonanie o własnej skuteczności, któremu towarzyszą między innymi dobre wyniki w nauce i „entuzjazm matematyczny”. Artykuł ten uzupełnia lukę w wiedzy na temat społecznego kontekstu wchodzenia na „matematyczną ścieżkę”, która dotychczas skupiona była przede wszystkim na kwestii niepowodzeń matematycznych wynikających z procesu dydaktycznego (np. Gruszczyk-Kolczyńska 2014), czy szerszego kontekstu społecznego (Breczko 2017). Tutaj przedmiotem analizy staną się czynniki, które przyczyniły się do pozostania na „matematycznej ścieżce".

\section{Wyniki szkolne i postrzeganie matematyki}

Porównanie wyników egzaminów gimnazjalnych sugeruje, że między chłopcami i dziewczętami nie ma systematycznych różnic. Badania obejmujące 
lata 2012 i 2013 (Skórska, Świst 2014) pokazują, że chłopcy mieli przeciętnie więcej punktów z matematyki na egzaminie gimnazjalnym (różnica między płciami była istotna statystycznie) tylko w pierwszym roku objętym analizą. Podobną jednoroczną przewagę na korzyść chłopców odnotowano też w przypadku historii, a dziewczyny miały z kolei wyższe wyniki z języka polskiego. Należy jednak podkreślić, że płeć wyjaśniała tylko znikomą część zróżnicowania wyników w testach gimnazjalnych wszystkich wspomnianych przedmiotów (Skórska, Świst, 2014). Inne analizy potwierdzają brak różnic na poziomie gimnazjalnym. Badania obejmujące dłuższą perspektywę czasu wskazują, że o ile w latach 2002-2007 chłopcy mieli nieznacznie wyższą średnią z części matematyczno-przyrodniczej, to w kolejnych latach wyniki odwróciły się na korzyść dziewcząt (Grudniewska, Kondratek, 2012). W części matematyczno-przyrodniczej tego egzaminu liczba zadań faworyzujących którą́ płeć, a więc takich, w których wyniki istotnie się różniły, była niewielka (najwięcej takich zadań było w 2006 roku - 9 na 34). Pewne prawidłowości zaobserwowano natomiast na poziomie szczegółowej analizy konkretnych zadań. Przykładowo, w zadaniach wieloetapowych dziewczęta lepiej radziły sobie z niektórymi operacjami, np. potrafiły skuteczniej niż chłopcy zidentyfikować informacje w zadaniu, ułożyć z nich równania i sprawniej dokonywać obliczeń (Grudniewska, Kondratek, 2012). Różnic ze względu na płeć nie zaobserwowano w części matematyczno-przyrodniczej w latach 2002-2011 również w innym badaniu (Szaleniec et al., 2013; Raport DKG, 2012).

Mniej wiadomo natomiast o zróżnicowaniach wyników egzaminów maturalnych, które decydują o podjęciu edukacji akademickiej. Istniejące, nieco starsze już opracowania wskazują, że wśród osób, które zdawały maturę z tego przedmiotu w 2010 roku na poziomie podstawowym i rozszerzonym, średni wynik kobiet był nieco wyższy niż wynik mężczyzn (RoSE, 2010). Istotniejsze zróżnicowanie widać było jednak w innym wymiarze: tylko $9 \%$ kobiet i $20 \%$ mężczyzn zdecydowało się zdawać ten przedmiot na poziomie rozszerzonym (RoSE, 2010). Wyniki egzaminacyjne Centralnej Komisji Egzaminacyjnej potwierdzają ten trend we wszystkich kolejnych latach i wskazują na niemal dwukrotnie mniejszy odsetek kobiet przystępujących do egzaminu rozszerzonego z matematyki (raporty CKE).

Badania nad psychologicznymi aspektami uczenia się matematyki wyjaśniają pochodzenie tych różnic. Wskazuje się, że kobiety odczuwają na ogół większą niepewność w sytuacji rozwiązywania zadań matematycznych (Cipora 2015), cechują się mniejszą pewnością siebie, niżej oceniają własną skuteczność w rozwiązywaniu zadań nawet jeśli ich obiektywne wyniki są wyższe do 
wyników chłopców (Turska 2013) i dokonują wewnętrznej atrybucji uznając siebie, a nie zewnętrzne czynniki, za źródło porażek w rozwiązywaniu zadań (Correll 2001). Inną przyczyną może być zjawisko zagrożenia stereotypem. Skutkuje ono obniżeniem skuteczności w wykonywaniu zadań w wyniku samej aktywizacji przekonania o niższych umiejętnościach określonej grupy (Drążkowski 2014). Uruchomienie stereotypu mówiącego, że dziewczęta mają niższe kompetencje matematyczne może wiązać się z faktycznie niższymi wynikami uzyskanymi w testach (Good, Aronson, Harder 2008). Można jednak przypuszczać, że siła tych czynników będzie uzależniona od rzeczywistych kompetencji. Z badań przeprowadzonych przez Turską (2013) wśród polskich gimnazjalistów wynika, że dziewczęta z oceną bardzo dobrą określały swoją skuteczności tylko nieco gorzej niż chłopcy z taką samą oceną, natomiast dziewczęta z oceną niedostateczną znacznie gorzej niż chłopcy (Turska 2013). Może to oznaczać, że na wpływ stereotypów narażone są przede wszystkim dziewczęta ze słabymi ocenami, które posługują się nierealistycznie niską oceną własnych kompetencji. Te z lepszymi wynikami powinny cechować się większą pewnością siebie, bardziej polegać na swoim wewnętrznym przekonaniu niż sygnałach płynących z zewnętrz, ale jak się okazuje nawet w tej grupie odnotowuje się obniżenie wyników, gdy aktywowane są treści stereotypowe (Good, Aronson, Harder 2008).

Wyniki badania PISA wskazują też, że w Polsce dziewczęta i chłopcy osiągnęli taki sam wynik na skali instrumentalnego uczenia się matematyki, a więc deklarowanej chęci wykorzystania tej wiedzy w przyszłej pracy zawodowej i edukacji (PISA, 2015). Deklaracje te mogą oznaczać jednak coś innego dla dziewcząt i chłopców. W przypadku tych pierwszych wiąże się to często z wyborem zawodu nauczycielki matematyki, a u mężczyzn studiów politechnicznych. Ma to swoje źródło m.in. w odmiennych oczekiwaniach wobec dziewczynek i chłopców. Jako ilustrację można przytoczyć wyniki sondażu CBOS z 2009 roku, w którym badani pytani byli o wymarzony zawód dla syna i córki. Pytanie postawiono badanym niezależnie od tego, czy faktycznie posiadali potomstwo, przez co silniej oddaje potoczne wyobrażenia niż indywidualne preferencje. Zawody związane z wykształceniem politechnicznym lub technicznym $21 \%$ badanych wybrałoby dla swojego syna, a tylko $1 \%$ dla córki (CBOS, 2009). Podobne wnioski płyną z badania przeprowadzonego przez IBE, z tym że te objęły wyłącznie osoby posiadające dzieci. Tylko $6 \% \mathrm{z}$ nich chciałoby, aby zawody inżynieryjne i techniczne wykonywała ich córka, natomiast zawodu takiego dla syna chciałoby prawie 30\% (Kozłowski, Matczak, 2012). Ta ogromna różnica nie może zostać bez wpływu na codzienne relacje z córkami i synami, wpajane wartości czy aspiracje. W jednym z badań Yee 
i Eccles (1988) pokazały, że rodzice inaczej lokowali źródło sukcesu ze względu na płeć dziecka - przyczyną dobrych wyników synów był talent, a dziewczynek wysiłek. Można zatem domniemywać, że dziewczynki rozwijają swoje zdolności matematyczne w na ogół mniej korzystnym środowisku społecznym niż chłopcy. Jeśli założyć, że wśród dziewcząt wzmacniane są takie cechy jak sumienność czy staranność, może to manifestować się wspomnianą wcześniej większą dokładnością w rozpisywaniu zadań, ale też mniejszą skłonnością do podejmowania „ryzyka” zaproponowania niekonwencjonalnego rozwiązania. Zależności te jednak są skomplikowane i o związkach przyczynowych należy wypowiadać się tu ostrożnie.

\section{Przekonanie o własnej skuteczności}

Wśród różnego rodzaju czynników, które sprzyjają nauce matematyki, a później podjęciu studiów, jest własne poczucie skuteczności. Sformułowana przez Alberta Bandurę $(1977,1997)$ teoria mówi, że ludzie będą bardziej skłonni podejmować te działania, co do których są przekonani, że dobrze sobie z nimi poradzą. Przekonanie o własnej skuteczności wpływa na sposób postrzegania rzeczywistości, reguluje zachowanie oraz poziom motywacji. Popycha ludzi ku działaniu, pomaga wytrwać i chroni przed zniechęcającymi skutkami niepowodzeń. Redukuje także lęki, które pojawiają się w sytuacjach, gdy ludzie nabierają przekonania, że pewne działania ich przerastają i sobie z nimi nie poradzą. Wpływa również na to, jak wiele wysiłku i energii zostanie włożone w realizację działania, które ma zakończyć się sukcesem. Skoro przekonanie o własnej efektywności jest kluczowe dla upartego dążenia do celu, należy zastanowić się, co je kształtuje. Bandura twierdzi, że ważne są tu informacje uzyskiwane z kilku źródeł. Pierwszym z nich są własne osiągnięcia w wykonywaniu określonych zadań. Rzeczywiste sukcesy na danym polu są silnym sygnałem świadczącym o własnej skuteczności i posiadanie ich zwiększa prawdopodobieństwo, że działanie będzie kontynuowane. Przeciwny efekt będą miały porażki, a szczególnie te poniesione na początkowym etapie. Jeśli więc uczeń lub uczennica od początku osiąga dobre wyniki w nauce, szybko nabiera przekonania, że jest „w tym dobry” czy „dobra”. Analogicznie, uważa się, że niepowodzenia matematyczne rozpoczynają się od pierwszego źle rozwiązanego zadania. Motywacja jest w tym ujęciu powiązana przyczynowo z wynikami: wiara w efektywność lokuje źródła swoich niepowodzeń w zbyt małym wysił$\mathrm{ku}$, natomiast ci, którzy mają przekonanie o niskiej efektywności, przypisują swoje niepowodzenia małym zdolnościom. 
Drugim elementem kształtującym poczucie własnej skuteczność według Bandury są informacje płynące od osób, które uważane są za podobne pod pewnymi względami. Pełni to funkcję doświadczeń zastępczych. Wpływ innych osób zilustrować można dziesiątkami badań, które dowodzą, jak dużą rolę w kształtowaniu postaw wobec matematyki ma najbliższe środowisko jednostki. Gunderson i zespół (2011) szczegółowo wyjaśnia, jak wartości i postawy przekazywane przez rodziców i nauczycieli w istotnym stopniu regulują własną samoocenę, a więc również przyszłe wybory szkolne. Domniemanie, że chłopcy są zdolniejsi już na starcie, może zniechęcić dziewczęta do rozwijania zdolności przez ulokowanie przyczyn niepowodzeń w nich samych, a nie w zewnętrznych czynnikach, takich jak niska motywacja do nauki. O pozytywnym wpływie modeli świadczy również badanie przeprowadzone przez Zeldin i Pajaresa (2000) wśród kobiet pracujących w zmatematyzowanych zawodach. Wynika z niego, że przebywanie w środowisku osób mających podobne doświadczenie było kluczowe dla wyboru kierunku kariery. Aż $2 / 3$ z przebadanych przez nich kobiet miało w swoich otoczeniu osoby związane ze zmatematyzowanymi zawodami. Obecność osób bliskich wiązała się też z werbalnym wsparciem, które wzmacniało pewność siebie i pozwalało rozwiewać pojawiające się wątpliwości. Poza rodziną, kluczową rolę odgrywali również nauczyciele, których pasja i oddanie wzmacniały wiarę we własne siły. Badacze są zgodni, że znaczący inni mają korzystny wpływ na wzrost zainteresowania kobiet kierunkami studiów z dziedzin naukowych i inżynieryjnych, ale nie wiadomo jakie dokładnie cechy powinien ten wzór posiadać. Można spotkać się z sugestiami, że korzystniejszy może być kontakt z kobietami będącymi reprezentantkami nauk ścisłych i technicznych, które będą ,żywym dowodem” tego, że taka kariera jest w ich zasięgu (Strout, 2011). Inni badacze zwracają jednak uwagę, że jeśli wzór osobowy postrzegany jest jako nieosiągalny, to może zniechęcić do działania (Lockwood i Kunda, 1997). Nie jest więc oczywiste, że spopularyzowany obecnie wizerunek medialny kobiet inżynierek występujących w roli specjalistek, profesjonalistek czy pasjonatek prezentowanych zazwyczaj na tle zaawansowanych urządzeń (Szymczak, 2015) będzie miał pozytywny wpływ na zainteresowanie kobiet tymi dyscyplinami.

Bandura odróżnia omówiony wyżej wymiar obserwacji sukcesów i porażek innych osób od werbalnych komunikatów przez nie wysyłanych. Te ostatnie wzmacniają przekonanie o własnej skuteczności, ale tylko w ograniczonym zakresie, ponieważ perswazja słowna wpływa przede wszystkim na osoby pewne swoich umiejętności. Ostatni aspekt skutecznego działania to w tej społeczno-poznawczej teorii fizyczne i emocjonalne stany związane z poczuciem spraw- 
czości. Przewiduje się, że nieprzyjemne doświadczenia emocjonalne, lęk, napięcie będą zniechęcały do podejmowania działań i w końcu doprowadzą do ich zaprzestania lub stosowania różnego rodzaju strategii unikowych. Jest to szczególnie ważne w przypadku matematyki, która częściej niż inne przedmioty wywołuje wśród uczniów poczucie niepokoju. Badaczka niepowodzeń szkolnych Edyta Gruszczyk-Kolczyńska (1992) stawia nawet mechanizmy emocjonalne w centrum uczenia się matematyki. Zauważa, że stres i frustracja pojawiające się przy rozwiązywaniu trudnych zadań prowadzą do stosowania rozbudowanych strategii unikania konfrontacji z nimi. Dzieci, zamiast kierować uwagę na rozwiązanie problemu, dają się ponieść negatywnym emocjom prowadzącym do dezorganizacji procesu nauki. Co ważne, te nieprzyjemne uczucia częściej towarzyszą kobietom niż mężczyznom (Cipora, 2015).

Empiryczne próby weryfikacji teorii Bandury nie przyniosły jednoznacznych rozstrzygnięć dotyczących wkładu poszczególnych czynników w poziom poczucia efektywności, ale na ogół wiodącą rolę przypisuje się ocenie własnych kompetencji (Usher, Pajares 2008). Poczucie „bycia w czymś dobrym” wydaje się szczególnie istotne w przypadku kobiet wybierających kariery w naukach technicznych ponieważ wybór ten wiąże się z koniecznością przekroczenia kulturowych ról. „Chodzeniu pod prąd” towarzyszyć mogą poczucie zagrożenia, wrażenie posiadania niższych kompetencji czy brak wiary w powodzenie, ale cztery źródła oczekiwanej skuteczności wskazane przez Bandurę mogą te obawy zminimalizować tworząc w jednostce przekonanie, że jest zdolna odnieść sukces.

\section{Próba badawcza}

Celem artykułu jest odpowiedź na pytanie o społeczne źródło przekonania o własnej skuteczności w zakresie kompetencji matematycznych dziewcząt zdolnych matematycznie. Interesowało mnie, jaki wpływ na kształtowanie się tego przekonania u kobiet miało środowisko rodzinne i szkoła. Analiza dotyczyć też będzie tego, jak młode kobiety postrzegają swoje własne umiejętności i jaką definicją siebie się posługują.

W ramach badania przeprowadzono 20 wywiadów jakościowych ze studentkami Uniwersytetu w Białymstoku i Politechniki Białostockiej. Połowa wywiadów przeprowadzona została ze studentkami kierunków ścisłych i przyrodniczych (fizyka, matematyka, biologia, chemia), a druga połowa ze studentkami kierunków technicznych (informatyka, elektrotechnika, budownictwo, mechanika i budowa maszyn). Semistandaryzowane wywiady przeprowadzone 
zostały według przygotowanego scenariusza, a treść rozmów poddano transkrypcji i kodowaniu przy użyciu pakietu RQDA dostępnego w środowisku R.

Jedynym kryterium rekrutacji do badania było studiowanie na kierunku wytypowanym do próby. W próbie znalazły się kobiety o zróżnicowanym statusie społeczno-ekonomicznym i wynikach w nauce. Badane pochodziły z miasta ulokowania uczelni bądź mniejszych, sąsiednich miejscowości. Były studentkami różnych lat studiów pierwszego stopnia ${ }^{1}$.

\section{Świadomość własnych kompetencji i entuzjazm matematyczny}

Teoria własnej skuteczności przewiduje, które działanie zostanie zrealizowane w oparciu na poczuciu kompetencji (Juczyński, 2000). Interesowało mnie zatem, jak tworzyło się przekonanie o własnej skuteczności, jak jest werbalizowane oraz jakie doświadczenia wpłynęły na jego ukształtowanie. Warto zwrócić uwagę, że opinie badanych - częściowo ze względu na to, że należą do kategorii osób, które już przeszły przez próg selekcji i obiektywnie potwierdziły swoje kompetencje, mogą wyrażać szczególną afirmację wobec własnej skuteczności.

Tym, co charakteryzuje badane kobiety, jest wysoka samoocena własnych kompetencji. Przejawiała się ona w wypowiedziach niemal wszystkich badanych. Posługując się potocznym stwierdzeniem, mówiły o sobie często: ,jestem umysłem ścisłym” lub „mam umysł ścisły”. Taka autodefinicja stanowiła fundament ich przekonania o własnych kompetencjach, spinała klamrą wszystkie ich szkolne doświadczenia i tworzyła spójną wizję samych siebie. Źródła tego przekonania są różnorakie, ale tak jak proponuje teoria własnej skuteczności, kluczowe były tu wyniki szkolne. Czynniki te są ze sobą skorelowane (Liu, Koirala, 2009). Wypowiedzi badanych były pod tym względem niezwykle podobne i jednoznacznie wskazywały na niezachwiane (w większości przypadków) poczucie kompetencji. Wyrażało się to m.in. w opiniach dotyczących łatwego opanowania matematyki. Dobrze ilustruje to poniższy cytat:

Zawsze byłam lepsza ze ścisłych przedmiotów, jakoś humanistyczne nigdy mi nie szły wbrew pozorom. I dlatego też fizykę bardzo szybko załapałam, już nawet w gimnazjum będąc. Nie miałam jakichś większych problemów nawet z przedmiotami typu chemia, biologia. To co bardziej było na zrozumienie jednak, to te przedmioty mi dużo lepiej szły.

${ }^{1}$ Badanie zrealizowane zostało z Grantu dla Młodych Naukowców przyznanego przez Uniwersytet w Białymstoku. 
Deklarowana przez badane łatwość opanowania matematyki, która nieraz korelowała z sukcesami z innych przedmiotów, szybko przekuwana była na sukcesy jeszcze bardziej wzmacniające przekonanie o matematycznych predyspozycjach. Udział w konkursach szkolnych oraz dobre oceny były mocnym sygnałem świadczącym o własnym talencie. Zdarzało się, że świadomość ta potwierdzana była również w inny sposób. Jedna ze studentek matematyki z poczuciem satysfakcji podkreśla swój udział w poprawieniu ocen z matematyki swoich młodszych krewnych:

No, ale jak każda z nich [kuzynek] miała jedynki, dwójki, a potem piątki przynosiła, no to jednak efekty są.

Wypowiedź ta dobrze ilustruje przekonanie o własnym sprawstwie, którego charakterystyczną cechą była wytrwałość. Wskazują na to zwroty takie jak ,ja zawsze wiedziałam" często używane do opisu swoich mocnych stron. Analizując wypowiedzi badanych, można dojść do wniosku, że odwołują się one do doświadczeń jeszcze wcześniejszych niż te zdobyte w szkole. Badane rzadko potrafiły jednak przywołać konkretne wydarzenia z dzieciństwa, które miałyby wpływ na wybór ich ścieżki rozwoju.

Przekonanie o własnych kompetencjach nie ograniczało się tylko do samookreślenia w kategoriach „umysłu ścisłego” ani dobrych ocen z przedmiotów ścisłych. Niemal wszystkie badane dziewczęta, mówiąc o sobie w kontekście doświadczeń szkolnych, podkreślały dystynktywne cechy intelektualne, które w ich przekonaniu odróżniają je od humanistów. Chodzi tu o określenia takie jak „logika”, „logiczne myślenie”, „branie na logikę”, używane do opisu strategii uczenia się. Oto jeden z przykładów:

Najłatwiej mi się w matematyce odnaleźć. Wolę rozwiązywać zadania, coś tam logicznie myśleć, układać, stworzyć, niż na przykład pisać długie wypowiedzi.

Logiczne myślenie wyróżnia matematykę spośród innych przedmiotów, które w ocenie badanych ograniczają się jedynie do konieczności pamięciowego opanowania faktów. Matematyka jest dyscypliną, która szczególnie weryfikuje umiejętność rozumowania, wnioskowania, szukania związków i przekładania tych zależności na język abstrakcyjnych symboli. Możliwość stosowania tych procedur sprawiała badanym niezwykłą satysfakcję. Można było nawet odnieść wrażenie, że biegłość pozwalała im na „bawienie” się tymi umiejętnościami. Pod względem pozytywnych atrybutów przypisywanych matematyce i swobo- 
dzie myślowej badane przeze mnie kobiety są całkowitym przeciwieństwem uczniów, którzy są bohaterami większości prac naukowych poświęconych niepowodzeniom matematycznym. Nie towarzyszy im wspomniany wcześniej niepokój i lęk (Cipora, 2015) czy związana z nimi bezradność matematyczna przejawiająca się brakiem umiejętności rozwiązywania nowych problemów (Kalinowska, 2010). Stosunek emocjonalny badanych kobiet można zilustrować następującym przykładem:

Najbardziej mnie satysfakcjonowało jak rozwiązywałam zadania, zrobiłam je i wszystko szło tak jak trzeba. Wiesz, w sensie, że idę i ja to rozumiem i wiesz o co chodzi. Albo robię to innym sposobem i też mi wyjdzie, nie? To mnie najbardziej satysfakcjonowało, że chciało się dalej robić te zadania. Denerwowało mnie to, jak coś mi nie wychodziło albo jak coś do końca nie zrozumiałam, to było wkurzające że: skąd to się wzięło?

Emocje, o których badane często mówiły w kontekście nauki matematyki, stają się ważnym komponentem motywacji w tym sensie, że informują jednostkę, czy dane działanie postrzegane jest jako zagrożenie, czy wyzwanie. W tym pierwszym przypadku wyzwalane są reakcje obronne, które przekierowują uwagę na inne czynności. Mogą też - co można było obserwować wśród naszych badanych - motywować do podjęcia działań mających na celu uniknięcie niepowodzenia (Boekartes, Pekrun, 2016). Dziewczęta, opowiadając o stosunku do matematyki, często wskazywały na fascynację tą dyscypliną, jej zróżnicowaniem i bogactwem. Dowody własnej skuteczności oraz pobudzenie emocjonalne są tu ściśle powiązane i wzajemnie się wzmacniają.

Wypowiedzi kobiet pozwalają też stwierdzić, że „oswoiły” matematykę traktowały ją jako element codziennego doświadczenia, nie unikały kontaktu z nią ani możliwości jej stosowania w sytuacjach pozaszkolnych. Jest to kolejna cecha, która odróżnia badane studentki od osób odczuwających niechęć wobec tej dziedziny. Afirmatywny stosunek do matematyki silniej niż cokolwiek, o czym była dotychczas mowa, świadczy o dystynktywności nastawienia badanych kobiet wobec dominującego w szkołach syndromu niechęci. Poniższy cytat oddaje to spostrzeżenie:

Bo matematyka jest wszędzie po prostu. Nawet właśnie takie rzeczy jak biologia jest opisywana przez matematykę, nie? Na przykład rozmnażanie się zwierząt albo jak rosną kwiaty, no to one właśnie są określone wzorem, znaczy wzór określa to. Wszystko da się opisać matematycznie. 
Ta i inne wypowiedzi wskazują, że centralnym czynnikiem, który przyczynił się do długotrwałego zainteresowania matematyką, było autentyczne przekonanie o własnych umiejętnościach. Towarzyszyła temu silna wewnętrzna motywacja, która zachęcała do ponoszenia dodatkowego wysiłku oraz kształtowała samodzielność uczenia się (Muriama et al., 2013). Śledząc wypowiedzi badanych kobiet, można było zauważyć symptomy stosowania „głębokiego” stylu uczenia się, który polega na wnikliwym rozumieniu wiedzy, w odróżnieniu od zapamiętywania faktów. Badane zbyt mało poświęciły jednak miejsca na omówienie własnych strategii zwiększających efektywność nauki, aby można było omówić to bardziej szczegółowo.

Warto jeszcze raz podkreślić, że ten niezwykle entuzjastyczny obraz doświadczeń edukacji matematycznej dokonywany jest z perspektywy dzisiejszych sukcesów. Cofając się myślami w przeszłość, obecne studentki „męskich” kierunków mogą chętniej uwypuklać zachowania i sytuacje, które korzystnie wpłynęły na ich późniejszy sukces, a rzadziej wskazywać na nawet drobne niepowodzenia. Najwyraźniej, nawet jeśli pojawiały się kłopoty lub wątpliwości, nie ma dla nich miejsca $\mathrm{w}$ obecnym sposobie postrzegania siebie jako osoby o wysokich umiejętnościach matematycznych.

\section{Źródła przekonania o własnej skuteczności}

Obok osiągnięć w wykonywaniu zadań oraz emocjonalnego pobudzenia, poczucie skuteczności kształtują też wzorce osobowe obecne w bliskim środowisku oraz słowna perswazja. Badane doświadczały tego wpływu przede wszystkim w szkole oraz domu rodzinnym. Wpływ najbliższego środowiska na wzmocnienie poczucia własnej kompetencji przejawiał się m.in. w pomocy otrzymywanej ze strony domowników. Jedna ze studentek wspomina konkretne wsparcie otrzymywane ze strony najbliższych:

w gimnazjum właśnie miałam problemy z matematyka a w podstawówce to już w ogóle. Ja beczałam, przychodziłam do domu, że nie umiem tego zadania, jak mnie już w szkole na matematyce nie było, to już kompletna klapa, nie? Zawsze tata siedziat ze mna i tam thumaczyt, coś pomagat.

W świetle wywiadów, pomocy w nauce ze strony osób bliskich potrzebowała tylko mniejszość badanych kobiet. Zdecydowana większość z nich doświadczała przede wszystkim wsparcia emocjonalnego, które albo łagodziło negatywne odczucia przyniesione ze szkoły, albo wzmacniało przekonanie 
o własnych zdolnościach. W biografiach niektórych badanych pojawiał się wątek nadawania etykiety „umysłu ścisłego”, tego, że to właśnie najbliższe środowisko rozpoznawało (choć niekoniecznie we wczesnym dzieciństwie) specjalne predyspozycje i wzmacniało je, formułując werbalne komunikaty. Badane kobiety dystansowały się jednak wobec sugestii, że członkowie ich rodzin mieli wpływ na ich decyzje o wyborze studiów czy też naukę matematyki na etapie szkolnym. W ich rozumieniu przyczyniły się do tego przede wszystkim ich własne zdolności, zainteresowania i chęci. Porównanie biografii kobiet pozwoliło zauważyć, że znaczna część badanych miała w swoim środowisku osobę lub osoby, które zdobyły doświadczenie w zakresie studiów ścisłych lub technicznych. Było to najczęściej rodzeństwo, kuzyni będący absolwentami lub studiujący na zmatematyzowanych kierunkach studiów. Ich obecność umożliwiała dostęp nie tylko do fachowej wiedzy, z której w razie potrzeby można było skorzystać, ale przede wszystkim stwarzała przekonanie o osiągalności celu, jakim jest biegłe opanowanie matematyki. Przypuszczalnie wiara we własne możliwości będzie większa, kiedy ma się świadomość, że brat czy rodzic również odniósł sukces w tej dziedzinie.

\section{Rola szkoły}

Wsparcie uzyskiwane $\mathrm{w}$ domu rodzinnym jest istotne, ale to szkoła ostatecznie weryfikuje, czy przekonanie o matematycznych zdolnościach ma pokrycie w rzeczywistości. W procesie dydaktycznym duże znacznie mają nauczyciele, od których oczekuje się, że będą potrafili zidentyfikować predyspozycje uczniów i w odpowiedni sposób je rozwinąć. Czy ten idealny model pracy $\mathrm{z}$ uczniem znalazł potwierdzenie w historiach naszych badanych? Na początek warto podkreślić, że wspomnienia dziewcząt o nauczycielach stanowią barwny katalog zróżnicowanych charakterów, temperamentów oraz stylów uczenia srodzy lub łagodni, sympatyczni lub autorytarni - mocno wbili się w pamięć studentek. Zróżnicowana ocena nauczycieli rozciąga się również na opinie o ich efektywności, a więc to, jak i czy potrafili rozbudzić ich „umysły ścisłe”. Ogromne różnice dostrzegalne są jednak nie tylko między historiami poszczególnych kobiet, ale również w pojedynczych biografiach kobiet, które na kolejnych etapach szkolnych miały różnych nauczycieli.

Modelowa sytuacja, w której nauczyciel lub nauczycielka skutecznie zaraża swoją pasją zdolną uczennicę, nie była rzadkością w biografiach naszych badanych. Jednak w niektórych przypadkach proces ,wchodzenia w matematykę" był bardziej złożony i nie miał tak systematycznego charakteru. Przykładem 
może być historia badanej, która w gimnazjum, dzięki zaangażowaniu nauczyciela, rozwijała się przede wszystkim w kierunku biologii. Oto jak wspomina zmianę swoich zainteresowań na matematykę w szkole średniej:

A już w liceum to już byta totalna odstona tego, miatam bardzo dobra (...) [nauczycielkę - AZ] matematyki. Potrafi zainspirować ucznia i dba po prostu o to, żeby się rozwijat.

Zmiana ta jest o tyle ciekawa, że w szkole gimnazjalnej ta młoda kobieta nie lubiła matematyki, ponieważ, jak sama wyjaśnia, ,nie odkryła” jej wtedy. Dopiero przygotowanie do egzaminu gimnazjalnego, a więc zwiększenie uwagi na tym przedmiocie, wzbudziło jej zainteresowanie na tyle, że kolejne trzy lata poświeciła niemal wyłącznie temu przedmiotowi. Zaowocowało to dobrze zdaną maturą i rozpoczęciem wymarzonych studiów. Warto zwrócić uwagę, że respondentka nawet $\mathrm{w}$ szkole gimnazjalnej lubiła matematykę i miała $\mathrm{z}$ niej dobre oceny, ale jak sama twierdzi, nauczyciel ,średnio wzbudzał zainteresowanie". Podobnej zmiany zainteresowań doświadczyła inna dziewczyna, która w szkole podstawowej stawiała bardziej na język polski, znowu ze względu na dobry kontakt z nauczycielem tego przedmiotu. O „matematyczce” wypowiadała się tak:

(...)Po prostu była złośliwa, była bardzo niemiła, była niesympatyczna(...). Pamiętam, że na złość nawet prac domowych nie odrabiałam. Bo tak to umiałam matematykę, (...), po prostu to było jej na złość.

W szkole gimnazjalnej badana trafiła na znacznie lepszą w jej ocenie nauczycielkę, która stawiała przed nią trudniejsze wyzwania i stymulowała do wytężonej nauki. Trwało to jednak tylko do końca tego etapu szkolnego, ponieważ w liceum znowu miała „okropną” nauczycielkę matematyki. Negatywne doświadczenia nie zniechęciły jej jednak do podjęcia studiów matematycznych, które z sukcesem realizuje. Godny podkreślenia wydaje się fakt silnego uzależnienia stosunku do przedmiotu od stylu pracy, a nawet stylu bycia nauczyciela. To m.in. te cechy, zupełnie niezależne od ucznia, dyktują niekiedy wybór kierunku nauki.

Rola nauczyciela jest szczególnie ważna w kontekście procesu wchodzenia w matematykę. Nie wszystkie badane interesowały się matematyką od początku nauki szkolnej. W literaturze szeroko opisywany jest problem wypadania z matematyki często już na pierwszym etapie formalnej edukacji, ale jak 
dowodzą wypowiedzi badanych, możliwe jest też „wpadnięcie” do matematyki na późniejszych szczeblach. Okazuje się, że matematyka nie musi być w centrum uwagi ucznia od szkoły podstawowej, aby kilkanaście lat później doszło do wyboru studiów z nią związanych. Wydaje się jednak, że odroczony zwrot ku matematyce będzie możliwy, o ile nie pojawiły się wcześniej nieprzyjemne doświadczenia związane z nauką, jak było to w przypadku niektórych badanych. Ważniejsze bowiem niż relacje z nauczycielem, choć i one odgrywają niebagatelną rolę motywacyjną, są oceny szkolne. Ostatecznie to stopnie stają się intersubiektywnym dowodem własnej skuteczności i właśnie na nich opiera się matematyczna samoocena. Wypowiedź jednej ze studentek matematyki trafnie oddaje tę prawidłowość:

moja nauczycielka z matematyki, jak kończyłam liceum, to zapytała mnie, gdzie ja się wybieram teraz. Ja mówię, że na matematykę. Ona mówi: Ty nawet tam się nie wybieraj, bo sobie nie poradzisz. Teraz chyba będę miała stypendium.

Warto podkreślić, że nawet jeśli badane kobiety od początku formalnej edukacji nie były zainteresowane matematyką, miały z tego przedmiotu dobre stopnie. Czasem brakowało jednak bodźca, który te predyspozycje mógł rozbudzić. Odroczone odkrycie matematycznych zainteresowań może mieć też związek z treścią programu nauczania, którego złożoność rośnie na późniejszym etapie nauki. Dopiero w szkole średniej uczniowie mogą w bardziej twórczy sposób korzystać z różnych narzędzi do rozwiązywania problemów matematycznych. Niektóre $\mathrm{z}$ badanych bagatelizowały naukę w szkole podstawowej czy gimnazjum, twierdząc, że na tych etapach można było jedynie uzyskać elementarną wiedzę, która nie stwarzała przestrzeni do kreatywnego myślenia.

Formalna edukacja wpłynęła w jeszcze inny, nieco zaskakujący sposób na kształtowanie poczucia matematycznej efektywności. W wywiadach często można było usłyszeć o niechęci wobec przedmiotów humanistycznych, które badane w pierwszej kolejności utożsamiały z uczeniem się na pamięć. Studentka fizyki wyraziła swój stosunek w następujący sposób:

O Jezu... Historia i polski. Nienawidziłam tych dwóch przedmiotów po prostu. Historii tylko i wyłącznie dlatego, że fakt faktem zapamiętywałam wszystkie daty, ale gorzej mi szło z przypasowaniem daty do wydarzenia. Po prostu nie szło mi kompletnie zapamiętywanie to, co trzeba było w sumie zapamiętywać, tak w sensie na przykład nazwy własne albo coś takiego, nigdy mi nie szło. 
Wypowiedzi te kontrastowane były zazwyczaj z koniecznością logicznego myślenia, zarezerwowaną zgodnie z opiniami badanych wyłącznie dla matematyki. Ciekawe zresztą, że negatywne opinie skierowane były nie wobec treści przedmiotów humanistycznych, ale właśnie wobec metody nauki. Zapamiętywanie faktów, dat i sztuka pisania wypracowań dla wielu z nich stanowiły większe wyzwanie niż całkowanie. Potwierdzałoby to potoczne przekonanie, że ,umysły ścisłe” gorzej radzą sobie z przedmiotami humanistycznym, jednak badane studentki miały często dobre stopnie również z tych przedmiotów. Musiały na nie jednak zapracować w inny sposób niż w przypadku matematyki.

Szkołę tworzą nie tylko nauczyciele, ale również rówieśnicy. Na podstawie wywiadów trudno jednoznacznie stwierdzić, jaki był ich wpływ na poczucie własnej skuteczności. Tylko niektóre badane opowiedziały o koleżankach lub kolegach mających podobne zainteresowania lub wspominały spędzanie wolnego czasu na przykład na wspólnym graniu na komputerze. Ważne wydają się jednak skutki selekcji między profilami nauki w szkole średniej. Prawie wszystkie badane studentki uczyły się na profilach związanych z naukami ścisłymi, przyrodniczymi lub politechnicznymi i przez okres licealny oddziaływali na nie rówieśnicy mający podobne zainteresowania. Względnie homogeniczne środowisko osób o zbliżonych umiejętnościach mogło być kolejnym istotnym źródłem wzmocnienia przekonania o wyborze dobrej ścieżki kariery.

Historie badanych kobiet przekonują, że rozwój umiejętności matematycznych dokonuje się na odpowiedniej „glebie”. Istnienie wzorów osobowych, zainteresowanie ze strony nauczyciela oraz brak negatywnych doświadczeń w nauce stanowią istotne źródło informacji o własnych umiejętnościach, a przeświadczenie to jest nieustannie weryfikowane w postaci ocen uzyskiwanych na testach, sprawdzianach czy klasówkach. Wydaje się, że to właśnie od pierwszych ocenianych postępów w matematyce uzależniony jest późniejszy stosunek do tego przedmiotu. Nieprzyjemne doświadczenia wywołane porażkami staną się sygnałem ostrzegawczym przed angażowaniem się w kolejne zadania. Taki scenariusz nie musi się jednak zrealizować, jeśli uczennica - jak pokazały to biografie niektórych kobiet mających początkowo problemy z nauką - uzyska wsparcie ze strony otoczenia społecznego.

\section{Dlaczego kobiety nie studiują na politechnice? Racjonalizacje niskiej partycypacji}

Analiza dotychczasowych wypowiedzi badanych wskazywała na rozmaite czynniki sprzyjające rozwijaniu wiedzy matematycznej i podjęciu studiów 
związanych z tą dziedziną. Obok nich występuje jednak cały szereg czynników zniechęcających, jak choćby stereotypy związane z zawodami technicznych czy brakiem odpowiednich ról do naśladowania. W kontekście istnienia tych barier, badane zapytane zostały o to, dlaczego inne kobiety niechętnie podejmuję studia politechniczne. Wypowiedzi te dają wgląd w świat ich własnych motywacji, ale są również syntezą obserwacji ich najbliższego, społecznego mikroświata.

Okazuje się, że podobnie jak o syndromie niepokoju matematycznego, można również mówić o występowaniu niepokoju technicznego. Jedna z badanych studentek w taki sposób wyjaśnia powody niskiego udziału kobiet:

Bo się boją. Wychodzę z założenia, że dziewczyny po prostu się boja albo po prostu, że nie czuly się z tym dobrze, że nie mialy z tym kontaktu wcześniej, tak? Że może się tym nie interesuja. Nie wynika z tego, że sa po prostu gtupsze, to na pewno nie o to chodzi, tylko po prostu jest albo jakiśs stereotyp, albo te dziewczyny się po prostu od razu boja nie wiadomo czego, bo nie chca się tego dotknać.

W odróżnieniu od lęku matematycznego, który wywoływany jest przez niepowodzenia w nauce tego przedmiotu, w tym przypadku źródłem negatywnych emocji staje właśnie brak doświadczeń z obiektami i urządzeniami, które w szczątkowej, symbolicznej postaci są reprezentacją „,wiedzy technicznej”. Jak trafnie ujęla to jedna $\mathrm{z}$ badanych:

Na pewno dziewczyna będąca na politechnice nie boi się czegoś takiego jak wymienić żarówki, nie boi się po prostu naprawić czegoś, coś tam zrobić, no jakaś taka zaradność życiowa jest większa myślę niż tych dziewczyn jednak studiujących ścisłe kierunki, bo one tam umysłem bardziej pracują.

Współcześnie takimi urządzeniami stają się komputery. Intuicje wyrażone w powyższym cytacie pokrywają się z wynikami badań, które pokazują, że dziewczęta w mniejszym stopniu korzystają z komputerów, czują się mniej pewne w ich używaniu i odczuwają większą obawę wobec ich stosowania w porównaniu do chłopców (He, Freeman 2009). Badane studentki należą wobec tego do mniejszości, która deklaruje obycie z komputerem, używanie go jako narzędzia rozrywki oraz nauki nierzadko od wczesnych lat szkolnych, a w części przypadków podejmującej też samodzielne próby programowania. Można przypuszczać zatem, że badane kobiet przełamały ów niepokój właśnie poprzez wcześnie rozpoczęty systematyczny trening. Nie zawsze jednak regularne ko- 
rzystanie z komputera wiąże się obniżeniem niepewności w jego stosowaniu. Komputer jest obecnie podstawowym wyposażeniem gospodarstw domowych, a jego używanie stało się elementem codziennych doświadczeń. Na ten aspekt zwraca uwagę studentka informatyki:

Dużo dziewczyn też siedzi przed komputerami, ale główne zainteresowania to film, muzyka, Facebook i na tym się kończy. A bycie informatykiem to juz niestety nie sa takie proste, latwe rzeczy. Trzeba dużo myśleć logicznie, dużo rozwiązywać zadań z matematyki. Dużo takich różnych nieciekawych rzeczy potrafić umieć. Myślę, że kobiety nie za bardzo sa tym zainteresowane.

Nie chodzi więc jedynie o to, aby obniżyć poziom obaw przez częstsze, ale pasywne posługiwanie się komputerem. Ważniejsze jest zrozumienie zasad funkcjonowania systemu, poznanie jego mechanizmów przez wykonywanie bardziej zaawansowanych aktywności czy samodzielne rozwiązywanie pojawiających się problemów. Wśród użytkowników aktywności te są zarezerwowane przede wszystkim dla mężczyzn, którzy wcześniej i bardziej intensywnie wchodzą w świat technologii.

Interesujące, że badane nie zlokalizowały źródeł mniejszego udziału kobiet na studiach inżynieryjnych w mniejszych predyspozycjach kobiet ani w stereotypach - ten wymiar pojawiał się wprawdzie w wypowiedziach badanych, ale nie był szczególnie eksponowany. Podkreślano za to rolę obaw odczuwanych wobec podjęcia trudnych ich mniemaniu studiów. Wydaje się, że w przekonaniu badanych ten właśnie czynnik, czyli obawa przed porażką na studiach inżynieryjnych kształtuje trwałe doświadczenia awersyjne u innych kobiet.

Być może obawa przypisywana przez badane innym kobietom jest projekcją ich własnych emocji, z którymi musiały się mierzyć w związku z przekraczaniem stereotypowych ról: najpierw były uczennicami uzdolnionymi matematycznie, a potem studentkami „męskich” kierunków studiów. Niektóre kobiety spotykały się w związku z tym z opiniami, że są ,mało kobiece” albo zdarzało się, że musiały uzasadniać w kontaktach z innymi wybór kierunku studiów. Zastanawiać się można, jaki wpływ na ich funkcjonowanie oraz wybory życiowe ma ten nonkonformizm wobec roli płciowej. Dalszych badań wymagałoby ustalenie, jakie czynniki decydują, że niektóre dziewczęta nie poddają się presji roli i ignorując stereotypy, wybierają nietypowe ścieżki karier szkolno-zawodowych. 


\section{Wnioski i dyskusja}

Bohaterkami tego artykułu są młode kobiety, które swoją karierę szkolną związały ze zmatematyzowanymi kierunkami nauki. Ich opowieści stanową ilustrację teorii własnej skuteczności zaproponowanej przez A. Bandurę. Przy jej użyciu przedstawiłam komponenty poczucia matematycznego sprawstwa, które przyczyniają się do trwałego zainteresowania tą dziedziną. Choć istnienie związku między poczuciem skuteczności a decyzją o podjęciu działań jest dość intuicyjne, wydaje się, że ciągle nie jest wystarczająco uwzględniany w praktyce uczenia matematyki.

Umiejętności matematyczne zajmują kluczowe miejsce wśród czynników wpływających na wybór zmatematyzowanego kierunku studiów. Nie mniej ważne okazuje się silne przeświadczenie o ich posiadaniu. Przekonanie o własnej skuteczności stanowi mieszankę poczucia sprawstwa, pewności siebie i ciekawości. Badane kobiety charakteryzowały się w ich przekonaniu nawet czymś więcej - ujmowały to w formie potocznego sformułowania jako ,umysł ścisły”. Świadomość taka była źródłem poczucia wyższości i pewności siebie. Bez wątpienia badane studentki lokują źródło własnego sukcesu w sobie, sugerując nawet, że zdolności nie są nabyte, ale raczej wrodzone. Nauka pomagała im w rozwijaniu, ale wiele $\mathrm{z}$ nich „od zawsze” wiedziało o swoich predyspozycjach. Analiza tła społecznego wskazuje jednak, że przekonanie o matematycznej skuteczności kształtowało się powiązaniu ze środowiskiem społecznym - poprzez interakcje $\mathrm{z}$ otoczeniem $\mathrm{w}$ szkole oraz $\mathrm{w}$ domu, rzadziej jego bezpośrednim źródłem byli rówieśnicy. Wraz z uzyskaniem etykiety „umysłu ścisłego" pojawiały się szczególne oczekiwania ze strony środowiska. Z badania wynika też, że poczucie skuteczności musi być podtrzymywane, ponieważ „wypadnięcie”, podobnie jak „wpadnięcie” do matematyki, może nastąpić również na wyższych etapach nauki. Zapobiega temu m.in. obecność w bliskim środowisku osób, które mają większe doświadczenie ze zmatematyzowanymi dziedzinami. Interesujące, że matematyczna tożsamość podtrzymywana była również przez niechęć do „wkuwania” przedmiotów humanistycznych, utożsamianych z innym sposobem myślenia. Autostereotyp „umysłu ścisłego” może być zatem niekiedy konsekwencją negatywnej oceny innych własnych zdolności poznawczych.

O dużym znaczeniu poczucia skuteczności dla podejmowanych decyzji usłyszeć można było również w wyjaśnieniach na temat niewielkiej liczby kobiet studiujących na politechnice. Strach, który blokuje przed podjęciem studiów w wieku wczesnej dorosłości, rodzi się znacznie wcześniej, gdy dziew- 
częta konsekwentnie unikają zadań, które w potocznym przekonaniu uważane są za „męskie”, trudne, czy też mało kobiece. W pewnej mierze odpowiada za to treść stereotypów na temat płci. Prawdopodobne jest, że niepokój towarzyszący nauce matematyki czy rozumieniu funkcjonowania urządzeń przynajmniej częściowo ma źródło w obawie przed przekroczeniem granic swojej roli płciowej i przed niekorzystnymi skutkami z tym związanymi. W wywiadach pojawiały się zresztą wypowiedzi wskazujące, że badane traktowane są przez swoje środowisko jako bardziej „męskie” z powodu posiadanych przez siebie umiejętności i studiowania na politechnicznych kierunkach studiów. Najwyraźniej jednak, za sprawą konfiguracji różnych czynników, koszt psychologiczny odstępstwa od normatywnych ról płciowych nie przekroczył w ich przypadku spodziewanych korzyści.

Wnioski z omówionego badania mogą mieć zastosowanie w praktyce dydaktycznej. Przeprowadzone analizy przekonują, że wiarę we własne kompetencje można w jednostce wytworzyć i wzmacniać poprzez umiejętne, stopniowe podnoszenie progu trudności zadań. Skoro ucieczka od matematyki rozpoczyna się od pierwszego niepowodzenia, to równie prawdopodobnie jest, że trwałe zainteresowanie matematyką ma swój początek właśnie w początkowych drobnych sukcesach. W szerszym kontekście zastanawiać się też można, czy matematyczne talenty kobiety i mężczyzn rozwijają się jednakowo pod wpływem takich samych bodźców. Istniejące dotychczas badania wskazują, że kobiety mają mniejsze szanse na rozpoczęcie karier w dziedzinach z zakresu zawodów technicznych i inżynieryjnych, ale większą skuteczność wobec nich niż mężczyzn wykazują różnego rodzaju działania mentoringowe czy afirmacyjne. Tego rodzaju wsparcie oferowane podczas ważnych etapów szkolnej edukacji (np. wyboru kierunku w szkole średniej, przedmiotów maturalnych) może mieć korzystny wpływ na zwiększenie udziału kobiet na kierunkach inżynieryjnych.

\section{Bibliografia}

Baczko-Dombi, A. (2017). Ucieczka od matematyki. Rekonstrukcja procesu w kontekście społecznego wizerunku przedmiotu, EDUKACJA Quarterly, 140(1), 39-54.

Bajcar, B., Borkowska, A., Czerw, A., Gąsiorowska, A., Nosal, C.S. (2006). Psychologia preferencji i zainteresowań zawodowych. Przegląd teorii i metod. Warszawa: Zeszyty Informacyjno-Metodyczne Doradcy Zawodowego, 34, Ministerstwo Pracy i Polityki Społecznej.

Bandura, A. (2007). Teoria społecznego uczenia się. Warszawa: Wydawnictwo Naukowe PWN. 
Bandura, A. (1994). Self-efficacy, W: V. S. Ramachaudran (red.), Encyclopedia of human behavior (s. 71-81). New York: Academic Press.

Benbow, C., Lubinski, D. (2003). Psychologiczny profil osób uzdolnionych matematycznie: niektóre różnice między ptciami i dowody wskazujace na ich biologiczny charakter, W: M. Roth Walsh (red.), Kobiety, mężczyźni i płeć. Warszawa: IFiS PAN.

Bedyńska, S., i Dreszer, J. (2006). Wyśmiej stereotyp! Czynniki redukujące zagrożenie stereotypem. Psychologia Społeczna, 02(02), 88-95.

Boekaerts, M., Pekrun, R. (2016). Emotions and Emotion Regulation in Academic Settings, W: L. Corno i E. M. Anderman (red.), Routledge Handbook of Educational Psychology. New York: Routledge.

Blickenstaff J. C.(2005). Women and science careers: leaky pipeline or gender filter?, Gender and education, 17(4), s. 369-386, DOI: 10.1080/09540250500145072.

Correll, S. J. (2001). Gender and the career choice process: The role of biased self-assessments. American Journal of Sociology, 106(6), 1691-1730. DOI: http://dx.doi. org/10.1086/321299.

CBOS. (2009). Aspiracje zawodowe Polaków. Jak osiągnąć sukces zawodowy?

Chomczyńka-Rubacha, M., i Rabacha, K. (2013). Test Poczucia Skuteczności. Opracowanie teoretyczne i psychometryczne Pracowni Narzędzi Badawczych Komitetu Nauk Pedagogicznych PAN. Przegląd badań edukacyjnych, 1(16), 85-105, DOI: 10.12775/ PBE.2013.007.

Cipora, K. (2015). Lęk przed matematyką z perspektywy psychologicznej i edukacyjnej. Edukacja, 1(132), s. 139-150.

Czerniawska, E. (2000). Interprzedmiotowe zróżnicowanie aktywności strategicznej, bezradność intelektualna i osiągnięcia w uczeniu się. Przegląd psychologiczny, 43(4), 499-512.

Good, C., Aronson, J., i Harder, J. A. (2008). Problems in the pipeline: Stereotype threat and women's achievement in high-level math courses. Journal of applied developmental psychology, 29(1), 17-28.

Drążkowski, D. (2014), Interwencje redukujące zagrożenia stereotypem w środowisku edukacyjnym, Edukacja, 3(128), s. 38-53.

Gąsiorowska, A., Bajcar, B. (2006), Kwestionariusz Zainteresowań Zawodowych - nowe narzędzie diagnostyczne dla doradcy zawodowego. W: Testy w poradnictwie zawodowym. Warszawa: Ministerstwo Pracy i Polityki Społecznej.

Gruszczyk-Kolczyńska, E. (1992). Dzieci ze specyficznymi trudnościami w uczeniu się matematyki. Przyczyny, diagnoza, zajęcia korekcyjno-wychowawcze. Warszawa: Wydawnictwa Szkolne i Pedagogiczne. 
Grudniewska, M., Kondratek, B. (2012). Zróżnicowane funkcjonowanie zadań w egzaminach zewnętrznych $w$ zależności od płci na przyktadzie części matematyczno-przyrodniczej egzaminu gimnazjalnego, XVIII Konferencja Diagnostyki Edukacyjnej, Wrocław.

Gunderson, E. A., Ramirez, G., Levine, S. C., Beilock, S. L. (2012). The role of parents and teachers in the development of gender-related math attitudes. Sex Roles, 66(3-4), $153-166$.

Główny Urząd Statystyczny. (2015). Szkoły wyższe i ich finanse 2014, Warszawa.

He, J., Freeman, L. A. (2009), Are Men More Technology-Oriented Than Women? The Role of Gender on the Development of General Computer Self-Efficacy of College Students. Journal of Information Systems Education, 21(2), 203-211, DOI:10.1037/e612132009$001 \% 20$.

Juszczyk, Z. (2000), Poczucie własnej skuteczności - teoria i pomiar, Acta Universitatis Lodziensis Folia Psychologica, 4(2000), 11-24.

Kalinowska, A. (2010). Pozwólmy dzieciom działać - mity i fakty o rozwijaniu myślenia matematycznego. Warszawa: Centralna Komisja Egzaminacyjna.

Kozłowski, W., Matczak, E. (2012), Aspiracje zawodowe rodziców w stosunku do własnych dzieci (raport z badań pilotażowych). Warszawa: Instytut Badań Edukacyjnych.

Liu, X., Koirala, H., (2009). The Effect of Mathematics Self-Efficacy on Mathematics Achievement of High School Students, NERA Conference Proceedings.

http://digitalcommons.uconn.edu/nera_2009/30

Lockwood, P., Kunda Z. (1997). Superstars and me: Predicting the impact of role models on the self. Journal of Personality and Social Psychology 73(1), 91-103. DOI: 10.1037/0022-3514.73.1.91

Rubacha, K. (2013). Uogólnione poczucie skuteczności a poczucie skuteczności wychowawczej rodziców i nauczycieli. Hipoteza sytuacyjnej zmienności, Studia Edukacyjne, 40, $75-83$.

Stout, J. G., Dasgupta, N., Hunsinger, M., \& McManus, M. A. (2011). STEMing the tide: using ingroup experts to inoculate women's self-concept in science, technology, engineering, and mathematics (STEM). Journal of personality and social psychology, 100(2), 255-270. DOI: 10.1037/a0021385

Skórska, P., Świst, K. (2014). Wielkość efektu płci w wewnątrzszkolnych i zewnątrzszkolnych wskaźnikach osiagnięé ucznia, „Diagnozy edukacyjne. Dorobek i nowe zadania”, XVIII Konferencja Diagnostyki Edukacyjnej, Wrocław

Szaleniec, H., Grudniewska, M., Kondratek, B. (2012). Analiza porównawcza wyników egzaminów zewnętrznych - sprawdzian w szóstek klasie szkoły podstawowej i egzamin gimnazjalny. Raport z badania. Zespół Dydaktyk Szczegółowych. 
Szymczak, E. (2015). Dziewczyny na Politechnikach - analiza wybranych przekazów reklamowych promujących przełamywanie stereotypów zawodowych i barier płciowych w obszarze męskich kierunków studiów, Studia Edukacyjne 36, 87-112. DOI: $10.14746 /$ se.2015.36.6

Turska, D. (2013). Poczucie autoskuteczności w matematyce uczniów i uczennic, Kultura i Edukacja 3(96), 98-115.

OECD (2013), PISA 2012 Results: Ready to Learn: Students' Engagement, Drive and Self-Beliefs (Volume III), DOI: 10.1787/9789264201170-en.

Murayama, K., Pekrun, R., Lichtenfeld, S., \& Vom Hofe, R. (2013). Predicting long-term growth in students' mathematics achievement: The unique contributions of motivation and cognitive strategies. Child development, 84(4), 1475-1490.

DOI: $10.1111 /$ cdev.12036.

Yee, D. K., \& Eccles, J. S. (1988). Parent perceptions and attributions for children's math achievement. Sex Roles, 19(5-6), 317-333. DOI: 10.1007/bf00289840

Zawistowska, A., (2013). Płeć matematyki. Zróżnicowania osiągnięć ze względu na płeć wśród uzdolnionych uczniów. Studia socjologiczne 3(210), 75-95.

Zeldin, A. L., \& Pajares, F. (2000). Against the odds: Self-efficacy beliefs of women in mathematical, scientific, and technological careers. American Educational Research Journal, 37(1), 215-246. DOI:10.3102/00028312037001215. 